\title{
The Effect of Leadership Style and Discipline of Work on Work Motivation as An Intervening Variable and Impact on the Performance of Teachers of Islamic Education Park, Gedangan Sidoarjo
}

\author{
Agung Dwi Nugroho $^{1 *} \quad$ Lisa Suryandari $^{1} \quad$ Sumarsid $^{2}$ \\ 1.School of Economics, STIE Mahardhika, Jalan Wisata Menanggal No.42 A Surabaya, Indonesia \\ 2.School of Management, Labora School of Management, Taman Modern Palem Raja Street Blok \\ B7 No. 7-8 Cakung Jakarta Timur Indonesia
}

\begin{abstract}
Research on the performance of teachers quite a lot done, then this study discusses the influence of leadership style, work discipline, and work motivation on teacher performance SMK Taman Pendidikan Islam Gedangan Sidoarjo. This study aims to re-examine the factors that affect the performance of teachers. This study aims to reexamine the factors that affect the performance of teachers. This research uses path analysis. This study entitled "EFFECT OF LEADERSHIP WORKING LEADERSHIP TO WORK MOTIVATION AND ITS IMPACT ON TEACHER SMK PERFORMANCE OF ISLAMIC EDUCATION GIDE SIDOARJO" where exogenous variables are leadership style (X1) and work disisplin (X2), intervening variable of work motivation (Z) and endogenous variable teacher performance (Y). The total population of 34 employees while the samples taken also 34 respondents for using saturated sampling technique. After going through a series of test that is Test Validity then the result is all valid, Reliability Test result is reliable, Normality test result of normal distributed data, Classical assumption test result free from classical assumption, Individual / Partial Test all significant variables. From the method of path analysis we get the equation of sub-structure 1 that is $Z=0,383 \mathrm{X} 1+0,576 \mathrm{X} 2+0,393 \mathrm{C} 1$ whereas equation sub structure 2 is $\mathrm{Y}=0,338 \mathrm{X} 1+0,319 \mathrm{X} 2+0,339 \mathrm{Z}+0,314 \mathrm{C} 1$. Coefficient of determination for sub structure 1 equal to $84,5 \%$ whereas coefficient of determination sub structure 2 equal to $90,1 \%$.
\end{abstract}

Keywords: Path Analysis, Leadership Style, Work Discipline, Work Motivation, Teacher Performance.

DOI: $10.7176 / \mathrm{JRDM} / 53-04$

Publication date:March $31^{\text {st }} 2019$

\section{Introduction}

Teachers are human resources who are in school, teacher performance is an important role in developing schools to be more advanced and qualified. The success of school performance is determined by the leadership style of school institutions that are firm and wise in taking leadership positions, to improve teacher performance to be more productive and to increase teacher enthusiasm. this kind of effort must be in the person of a leader who will be useful in the organization. And the task of a leader that needs to be done to make self-assertive and wise ones is to be able to accept opinions or accommodate suggestions from subordinates so that they can be reviewed for truth and take appropriate actions as appropriate in organization.

Human resources are one of the most important things for the implementation of teacher work activities in schools. Many factors influence teacher performance, for example the principal's leadership style as a leader, work discipline that is adhering to organizational norms or rules and work motivation that can encourage the enthusiasm of the subordinates and their impact on teacher performance. According to Wijaya Supardo in Adad Danuarta (2014), Leadership Style is a complex way and process where someone influences other people to achieve a mission, task or goal and direct the organization in a more reasonable way. According to Terry in Edy Sutrisno (2016: 86), discipline is the driving force of employees, so that each work can run smoothly, it must be endeavored so that there is good discipline. Work Motivation is encouragement or morale that originates both from within (internal) and from outside (external) to do a job with the best in order to produce better performance. Work Motivation given to someone is only effective when in a person has confidence or confidence to progress and succeed in the organization. Motivation is the impact of the interaction of someone with a particular situation that they will face, According to Mulyadi (2016: 88). Therefore, one of the best ways to improve employee performance is to maximize the Leadership Style, Work Discipline, Work Motivation and improve employee performance. With the presence of a Leadership Style and Motivation Good work should be an encouragement to create more optimal performance from an employee. With maximum performance from each individual involved, of course, will give the best results for overall performance. Not only superior in competition, but also able to increase profitability.

\section{Theoretical basis}

Human Resource Management can be defined as a management and utilization of existing resources in individuals. 
Furthermore, it was stated that Human Resource Management is a planning, organizing, implementing and overseeing the procurement, development, remuneration, integration, maintenance and separation of workers in order to achieve organizational goals, Mangkunegara in Sinambela (2016: 8).

The objectives of human resource management do not necessarily reflect the will of senior management, but must also balance the challenges of the organization, the functions of human resources, the community and the people affected. There are four objectives of human resource management, Simamora in Akbar (2013: 12), namely: 1. Social Goals The social purpose of human resource management is for organizations to be socially and ethically responsible for the needs and challenges of society while minimizing the negative impact of those demands on the organization. The implication is that some organizations link their resources to things like environmental health programs, environmental improvement projects, minority training and development programs, and organizing and sponsoring various art events.

2. Organizational Objectives

Organizational goals Human resource management is a formal target organization that is made to help the organization achieve its goals.

3. Functional Objectives

The functional purpose of human resource management is to maintain the contribution of the human resources department at a level that is appropriate to the needs of the organization. Resource waste will occur if human resource management is too sophisticated or less sophisticated than the needs of the organization. Human resource management must face increasing complexity in managing human resources by providing sophisticated consultations, for example in terms of organizational research, selection and development.

4. Personal Purpose Personal goals are the individual goals of each member of the organization to be achieved through their activities within the organization. If the personal goals and objectives of the organization are not suitable or not harmonious, then the employee may choose to withdraw from the organization.

From the information, it can be seen that human resource management is used as a tool or bridge to regulate and process human resources to achieve organizational goals. Each job has a different purpose, but in an organization employees are required to be able to maximize the quality of work results with leadership style and work discipline and the impact of work motivation on the performance of the teacher. Understanding leadership style is a leadership style is a comprehensive pattern of the actions of a leader both visible and unseen by his subordinates. The leadership style describes the philosophy that is consistent, skillful, the nature and attitude that underlies a person's behavior. Leadership style will show directly about a leader's confidence in the abilities of his subordinates. This means that leadership style is behavior and strategy, as a result of a combination of philosophy, skills, traits, attitudes, which are often applied from a leader when he tries to influence the performance of his subordinates, according to Rorimpandey in the research journal Awang Lenggowo (2016: 22).

In addition to leadership style, discipline is very important for the growth of the organization, mainly used to motivate employees to discipline themselves in carrying out work both individually and in groups. In addition, discipline is also useful to educate employees in complying with and enjoying existing regulations, procedures and policies so as to produce good performance. Discipline is the most important HR Management operative function because the better employee discipline, the higher the work performance that can be achieved. Good discipline reflects the amount of one's responsibility towards the tasks assigned to him.

According to Sinambela (2016: 335), Work Discipline is the awareness and willingness of employees to comply with all organizational regulations and prevailing social norms. Thus, work discipline is a tool used by leaders to communicate with employees so that they are willing to change their behavior according to the rules set. Discipline must be enforced in an organization. That is, without the support of good employee work discipline, it is difficult for the organization to realize its objectives. So, discipline is the key to the success of an organization in achieving its goals.

Every organization certainly wants to achieve its goals. To achieve this goal, the role of humans involved in it is very important. To move humans to be in accordance with what the organization wants, it must be understood that human motivation works within the organization, because this motivation determines people's behavior to work, or in other words, behavior is the simplest reflection of motivation. According to Edy Sutrisno (2014: 109) Motivation is a factor that encourages a person to do a certain activity, therefore motivation is often interpreted as a driving factor for one's behavior. Motivation is the impact of a person's interaction with a particular situation that he will face.

From the information above the leadership style and work discipline on work motivation have an important influence on performance in an organization, because of that Performance is the result of work that can be achieved by a person or group of people in an organization, in accordance with their respective authorities and responsibilities, in an effort achieving the objectives of the relevant organization legally, not violating the law and in accordance with morals and ethics, Prawirosentono in Sinambela (2016: 481). This explains that performance is the level of success of a person or institution in carrying out its work.

According to Rivai and Basri in Sinambela (2016: 482), performance is the result or level of success of a 
person or the whole during a certain period in carrying out tasks compared to various possibilities, such as work results standards, targets or targets or criteria that have been determined in advance and agreed together. From some expert opinions it can be concluded that employee performance is the result of work done by someone in an organization in order to achieve the desired goals of an organization and minimize losses and be able to create reliable employees who are able to carry out their duties according to the responsibilities given.

\section{RESEARCH METHODS}

The method used in this study is quantitative analysis research method because it explains the causal relationship between variables in the research model, namely leadership style and work discipline on work motivation as an intervening variable and the impact on the performance of teachers of Islamic education in the Sidoarjo Islamic Education Park.

Quantitative research methods are structured research and quantify data to be generalizable. The data used is data that is measurable, then processed with a quantitative approach, namely the testing of hypotheses used mathematical calculations with statistical formulas about the relationship between variables studied and produce conclusions that can be generalized (Sugiyono, 2013).

According to Sugiyono (2011: 80), Population is the overall subject of research. Whether someone wants to examine all the elements in the research area, the research is population research or population studies or census studies. Sugiyono (2011: 80), Samples are parts or quantities and characteristics possessed by the population. If the population is large, and researchers are unlikely to learn everything in the population, for example due to limited funds, energy and time, the researcher will take samples from that population.

Based on the theory of Sugiyono, (2011:68). the population used in this study were 34 teachers of the Vedic School of Islamic Education in Gedangan Sidoarjo. The sampling technique used is the census method, which is taking all members of the population into a sample. The use of this technique is due to the very small number of employees of the Vocational School of Islamic Education in Gedangan Park, Sidoarjo. So in this study the number of samples was 34 respondents, because it used a saturated sampling technique.

The type of data used in this study is primary data. The method of data collection uses a questionnaire. For data analysis using Validity Test, Reliability Test, Normality Test, Classical Assumption Test (Heterocedasticity Test and Multicollinearity Test), Hypothesis Testing (Path Analysis), T Test, Determination Coefficient Test ( $\left.\mathrm{R}^{2}\right)$, and Sobel Test). This path analysis is used to find out how much influence the independent variables, namely: Leadership style (X1) and work discipline (X2) on intervening variables Work motivation (Z) which affects the dependent variable teacher performance $(\mathrm{Y})$. The path analysis equation is as follows:

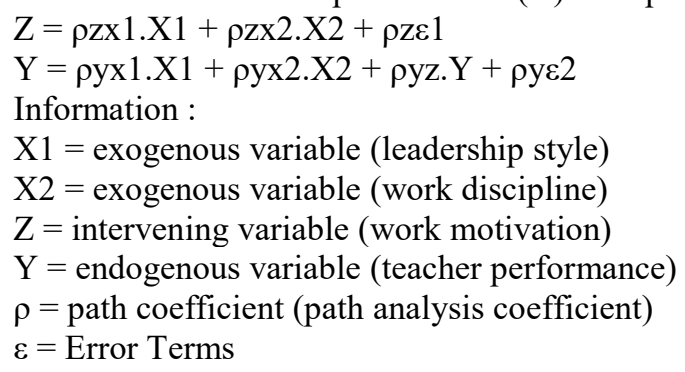

\section{RESULTS AND DISCUSSION}

Measurement of the Validitas Test in this study shows the amount of variance of the extracted indicator or latent variable developed. known results of Validity Test are as follows: 
Table 4.17 Validity test

\begin{tabular}{|l|l|l|}
\hline Variable & Corrected Total Item Correlation & Description \\
\hline Leadership Style 1 & 0,530 & Valid \\
\hline Leadership Style 2 & 0,692 & Valid \\
\hline Leadership Style 3 & 0,397 & Valid \\
\hline Work Discipline 1 & 0,653 & Valid \\
\hline Work Discipline 2 & 0,507 & Valid \\
\hline Work Discipline 3 & 0,786 & Valid \\
\hline Work Motivation 1 & 0,637 & Valid \\
\hline Work Motivation 2 & 0,833 & Valid \\
\hline Work Motivation 3 & 0,792 & Valid \\
\hline Teacher Performance 1 & 0,725 & Valid \\
\hline Teacher Performance 2 & 0,816 & Valid \\
\hline Teacher Performance 3 & 0,794 & Valid \\
\hline
\end{tabular}

Source: SPSS output results

From table 4.5 it is known that all indicators in a variable have a value of Corrected Total Item Correlation that is greater than 0.3 so that the data can be said to pass the Test Validity.

Reliability Test in this study to measure the consistency of respondents in answering questionnaires, the test results can be seen from the table below:

Table 4.18

Reliability Test

\begin{tabular}{|l|l|l|}
\hline Variabel & Cronbachs Alpha If Item Deleted & Description \\
\hline Leadership Style 1 & 0,922 & Reliabel \\
\hline Leadership Style 2 & 0,913 & Reliabel \\
\hline Leadership Style 3 & 0,926 & Reliabel \\
\hline Work Discipline 1 & 0,915 & Reliabel \\
\hline Work Discipline 2 & 0,920 & Reliabel \\
\hline Work Discipline 3 & 0,909 & Reliabel \\
\hline Work Motivation 1 & 0,915 & Reliabel \\
\hline Work Motivation 2 & 0,907 & Reliabel \\
\hline Work Motivation 3 & 0,909 & Reliabel \\
\hline Teacher Performance 1 & 0,912 & Reliabel \\
\hline Teacher Performance 2 & 0,907 & Reliabel \\
\hline Teacher Performance 3 & 0,910 & Reliabel \\
\hline
\end{tabular}

Sumber : Hasil output SPSS

Teacher Performance 30.910 Reliable Source: SPSS output results From the table above, it is known that all indicators in this study have a Deleted Cronbachs Alpha If Item value that is greater than 0.60 so that it can be said that it has passed the Reliability Test.

Normality test aims to find out whether in the path analysis model, the confounding or residual variables have a normal distribution or not. A good data model is normally distributed or near normal. To view normally distributed data, pay attention to normal probability plots on scatter plots with normal distribution. The test results can be seen from the picture below: 


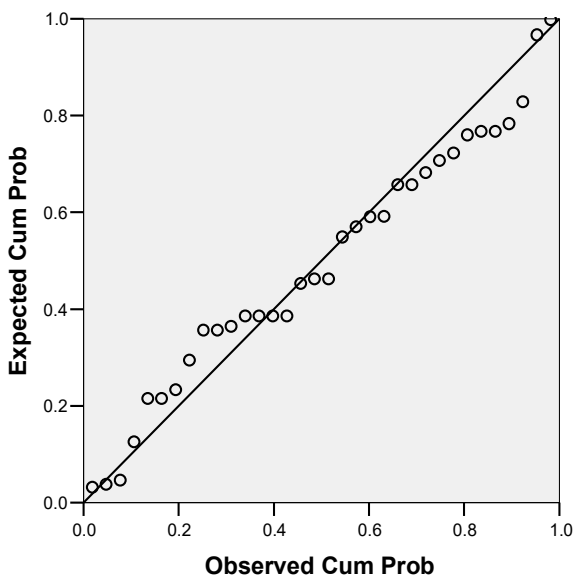

Figure 4.2 Normality Test

Source: SPSS output results

Based on the probability plot the above model can be seen that the residual plot spreads (follows) around the diagonal line to the right. This means that the residuals are declared to be normally distributed. Thus the normality test is fulfilled.

\section{Classic assumption test}

\section{A. Heteroscedasticity Test}

Heteroscedasticity test is used to find out whether the residual has a homogeneous (constant) variety or not. It is expected that the residual heteroscedasticity test will have a homogeneous variety. Testing for heterocedasticity tests can be seen through the Scatter Plot. The test criteria state that the residual points spread randomly (not forming a certain pattern) so that the assumption of heteroscedasticity is fulfilled. The following are the results of testing the assumption of heterocedasticity can be seen from the picture below:

\section{Scatterplot}

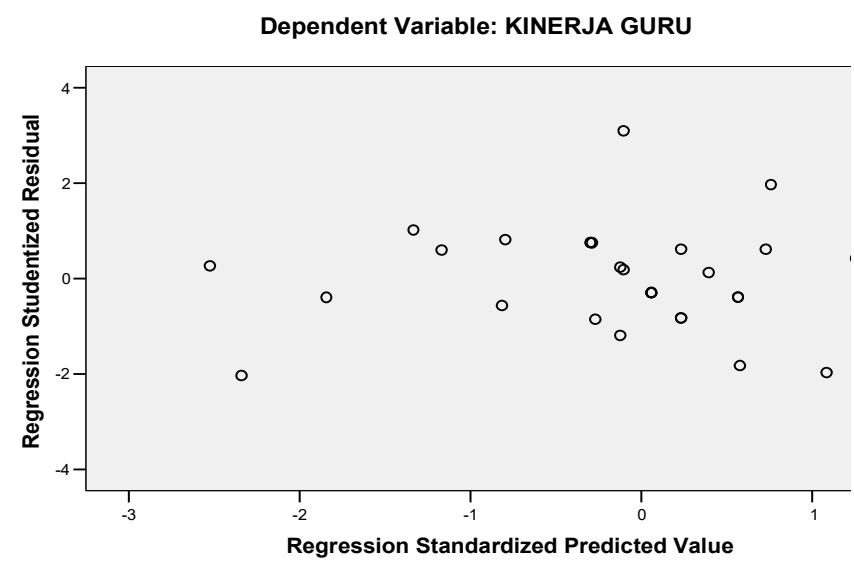

Figure 4.3 Heteroscedasticity Test

Source: SPSS output results

The test results of heteroscedasticity tests using scatter plots can be seen that the residual points produced by the two models spread randomly. Thus heteroscedasticity tests are fulfilled.

B. Multicollinearity Test

Multicollinearity test aims to test whether in the path analysis model there is a correlation between independent variables. A good path analysis model should not have a correlation between independent variables. Detect multicollinearity by looking at tolerance and the opponent's VIF. A low tolerance value is equal to a high VIF value indicating a high degree of collinearity. Multicollinearity test results can be seen in the table below: 
Table 4.19

Multicollinearity Test \& Dominant Variables

Coefficients a

\begin{tabular}{|ll|r|r|r|r|r|}
\hline \multirow{2}{*}{ Model } & \multicolumn{2}{|c|}{ Correlations } & \multicolumn{2}{c|}{ Collinearity Statistics } \\
\cline { 3 - 7 } & & \multicolumn{1}{|c|}{ Zero-order } & \multicolumn{1}{c|}{ Partial } & \multicolumn{1}{c|}{ Part } & \multicolumn{2}{c|}{ Tolerance } \\
\hline 1 & GAYA KEPEMIMPINAN &, 894 &, 467 &, 166 &, 242 & 4,136 \\
& DISIPLIN KERJA &, 902 &, 401 &, 138 &, 188 & 5,325 \\
& MOTIVASI KERJA &, 915 &, 391 &, 134 &, 155 & 6,434 \\
\hline
\end{tabular}

a. Dependent Variable: KINERJA GURU

Source: SPSS output results

From the data in the table above it can be seen the value of the Variance Inflation Factor (VIF) of each variable, namely the Leadership Style of 4.136, Work Discipline of 5.325, Work Motivation of 4.276. Then it can be concluded that there are no symptoms of multicollinearity between independent variables. all of these variables have a Variance Inflation Factor (VIF) value that is less than 10 and greater than 0.1 so that it can be said that the questionnaire results are free from multicollinearity. So that it can be said that the data has passed the Multicollinearity Test.

Path Analysis / Path Analysis

This analysis is used to determine how much influence the independent variables are: Leadership Style (X1), Work Discipline (X2) on Work Motivation as an intervening variable (Z) and Teacher Performance (Y) as the dependent variable. The path analysis equation is as follows:

\section{A. Sub Structure 1}

a) Equation Path Analysis / Path Analysis

In this study the path analysis / path analysis equations are as follows:

$Z=\rho z x 1 . X 1+\rho z x 2 . X 2+\rho z . E 1$

From the results of SPSS processing the following results are obtained:

Table 4.20

Path Analysis Coefficient and Test t Sub Structure 1

Coefficients ${ }^{\text {a }}$

\begin{tabular}{|c|c|c|c|c|c|c|}
\hline \multirow{2}{*}{\multicolumn{2}{|c|}{ Model }} & \multicolumn{2}{|c|}{$\begin{array}{l}\text { Unstandardized } \\
\text { Coefficients }\end{array}$} & \multirow{2}{*}{$\begin{array}{c}\text { Standardized } \\
\text { Coefficients } \\
\text { Beta }\end{array}$} & \multirow[b]{2}{*}{$\mathrm{t}$} & \multirow[b]{2}{*}{ Sig. } \\
\hline & & $\mathrm{B}$ & Std. Error & & & \\
\hline \multirow[t]{3}{*}{1} & (Constant) &,- 535 & 766 & &,- 698 & ,490 \\
\hline & GAYA KEPEMIMPINAN & ,411 & 135 & ,383 & 3,031 & ,005 \\
\hline & DISIPLIN KERJA & ,687 & 151 &, 576 & 4,554 &, 000 \\
\hline
\end{tabular}

a. Dependent Variable: MOTIVASI KERJA

Source: SPSS output results

Table 4.21 Determination Coefficient Sub Structure 1

Model Summaryb

\begin{tabular}{|l|r|r|r|r|r|}
\hline Model & \multicolumn{1}{|c|}{$\mathrm{R}$} & R Square & $\begin{array}{c}\text { Adjusted } \\
\text { R Square }\end{array}$ & $\begin{array}{c}\text { Std. Error of } \\
\text { the Estimate }\end{array}$ & $\begin{array}{c}\text { Durbin- } \\
\text { Watson }\end{array}$ \\
\hline 1 &, $919^{\mathrm{a}}$ &, 845 &, 835 &, 89432 & 2,103 \\
\hline
\end{tabular}

a. Predictors: (Constant), DISIPLIN KERJA, GAYA KEPEMIMPINAN

b. Dependent Variable: MOTIVASI KERJA

Source: SPSS output results

Based on tables 4.20 and 4.21 , the path analysis / path analysis equation is obtained as follows:

$Z=0.383 X 1+0.576 \times 2+\sqrt{ }(1-R$ Square $) \epsilon 1$

$Z=0.383 X 1+0.576 \times 2+\sqrt{ }(1-0,845) € 1$

$Z=0.383 \mathrm{X} 1+0.576 \mathrm{X} 2+0.393 € 1$

b) T test / Partial Test

The partial test / $t$ test carried out in this study are as follows:

a. Leadership Style Variables

The t-test / Partial test hypotheses used in this study are as follows:

Ho: Partial leadership style has no significant effect on work motivation. 
Ha: Partial leadership style has a significant effect on work motivation.

In this study using a confidence level of $5 \%$.

From table 4.20, it is known that leadership style variables have a sig value of 0.005 (equal to 0.05 ) so reject $\mathrm{H} 0$ and accept $\mathrm{H} 1$ means that the leadership style partially has a significant effect on work motivation.

b. Work Discipline Variables

The t-test / Partial test hypotheses used in this study are as follows:

Ho: Work discipline partially has no significant effect on work motivation.

Ha: Work discipline partially has a significant effect on work motivation.

In this study using a confidence level of 5\%. From table 4.20, it is known that work discipline variables have a sig value of 0,000 (less than 0.05 ) so that reject $\mathrm{H} 0$ and accept $\mathrm{H} 1$ means that work discipline partially has a significant effect on work motivation.

c) The amount of influence / contribution each - each variable

The amount of influence / contribution of each variable is as follows:

a. Contribution of Leadership Style Variables to Work Motivation Based on table 4.20 the influence / contribution of leadership style variables on work motivation is $0.383 \times 0.383 \times 100 \%=14.66 \%$

b. contribution of Variables in Work Dissipin to Work Motivation Based on table 4.20 the influence / contribution of work discipline variables on work motivation is $0.576 \times 0.576 \times 100 \%=33.17 \%$

d) Coefficient of Determination / R2

The determination coefficient value is determined by the $\mathrm{R}$ square value as can be seen from table 4.21 , it is known that the coefficient of determination / R2 is 0.845 . meaning that the leadership style variables and work discipline simultaneously contribute to work motivation, this means $0.845=84.5$, which is $100 \%-84.5=15.5 \%$. Then the remaining $15.5 \%$ is influenced by other variables not submitted in this study.

B. Sub Structure 2

a) Equation Path Analysis / Path Analysis

In this study the path analysis / path analysis equations are as follows:

$\mathrm{Y}=\rho \mathrm{yx} 1 . \mathrm{X} 1+\rho \mathrm{yx} 2 . \mathrm{X} 2+\rho \mathrm{z} . \mathrm{Z}+\rho \mathrm{y} . \mathrm{C} 2$

From the results of SPSS processing the following results are obtained:

Table 4.22

Path Analysis Coefficient and Test t Sub Structure 2

Coefficients ${ }^{\text {a }}$

\begin{tabular}{|c|c|c|c|c|c|c|}
\hline \multirow{2}{*}{\multicolumn{2}{|c|}{ Model }} & \multicolumn{2}{|c|}{$\begin{array}{c}\text { Unstandardized } \\
\text { Coefficients }\end{array}$} & \multirow{2}{*}{$\begin{array}{c}\begin{array}{c}\text { Standardized } \\
\text { Coefficients }\end{array} \\
\text { Beta }\end{array}$} & \multirow[b]{2}{*}{$\mathrm{t}$} & \multirow[b]{2}{*}{ Sig. } \\
\hline & & B & Std. Error & & & \\
\hline & (Constant) &,- 499 & 626 & &,- 798 &, 431 \\
\hline & GAYA KEPEMIMPINAN & ,361 & , 125 & ,338 & 2,892 & 007 \\
\hline & DISIPLIN KERJA & ,379 & , 158 & ,319 & 2,400 & 023 \\
\hline & MOTIVASI KERJA & ,339 & 146 & ,339 & 2,326 & ,027 \\
\hline
\end{tabular}

a. Dependent Variable: KINERJA GURU

Source: SPSS processed products

Table 4.23

Determination Coefficient of Sub Structure 2

Model Summaryb

\begin{tabular}{|l|r|r|r|r|r|}
\hline Model & R & R Square & $\begin{array}{c}\text { Adjusted } \\
\text { R Square }\end{array}$ & $\begin{array}{c}\text { Std. Error of } \\
\text { the Estimate }\end{array}$ & $\begin{array}{c}\text { Durbin- } \\
\text { Watson }\end{array}$ \\
\hline 1 &, $949^{\mathrm{a}}$ &, 901 &, 891 &, 72489 & 1,619 \\
\hline
\end{tabular}

a. Predictors: (Constant), MOTIVASI KERJA, GAYA KEPEMIMPINAN, DISIPLIN KERJA

b. Dependent Variable: KINERJA GURU

Source: SPSS output results

Based on tables 4.22 and 4.23, the path analysis / path analysis equation is obtained as follows:

$\mathrm{Y}=0.338 \mathrm{X} 1+0.319 \mathrm{X} 2+0.339 \mathrm{Z}+\sqrt{ }(1-\mathrm{R}$ Square $) \mathrm{E} 2$

$\mathrm{Y}=0.338 \mathrm{X} 1+0.319 \mathrm{X} 2+0.339 \mathrm{Z}+\sqrt{ }(1-0.901) \mathrm{C} 2$

$\mathrm{Y}=0.338 \mathrm{X} 1+0.319 \mathrm{X} 2+0.339 \mathrm{Z}+0.314 \mathrm{C} 1$

b) T test / Partial Test

The partial test / $\mathrm{t}$ test carried out in this study are as follows:

a. Leadership Style Variables

The t-test / Partial test hypotheses used in this study are as follows:

Ho: Partial leadership style has no significant effect on teacher performance. 
Ha: The leadership style partially has a significant effect on teacher performance.

In this study using a significant 0.05 or $5 \%$. From the results seen in table 4.22 coefficientsa, it can be seen the value of the results of beta for leadership style variables of 0.338 and the amount of tcount is 2.892 with a significant value of 0.007 so that $<0.05$ or $5 \%$. This means that Ho is rejected and Ha is accepted, namely the leadership style partially has a significant effect on Teacher Performance.

b. Work Discipline

Variables The t-test / Partial test hypotheses used in this study are as follows: Ho: Work discipline partially has no significant effect on teacher performance. Ha: Work discipline partially has a significant effect on teacher performance. In this study using a significant 0.05 or $5 \%$. From the results seen in table 4.22 coefficientsa, it can be seen the value of the results of beta for work discipline variables of 0.319 and the amount of tcount of 2.400 with a significant value of 0.023 so $<0.05$ or $5 \%$. This means that Ho is rejected and Ha is accepted, ie the work discipline partially has a significant effect on Teacher Performance.

c. Work Motivation

Variables The t-test / Partial test hypotheses used in this study are as follows: Ho: Work motivation partially does not have a significant effect on teacher performance. Ha: Work motivation partially has a significant effect on teacher performance. In this study using a significant 0.05 or 5\%. From the results seen in table 4.22 coefficientsa, it can be seen the value of the results of beta for work discipline variables of 0.339 and the amount of tcount is 2.326 with a significant value of 0.027 so $<0.05$ or $5 \%$. This means that Ho is rejected and Ha is accepted, namely work motivation partially has a significant effect on Teacher Performance.

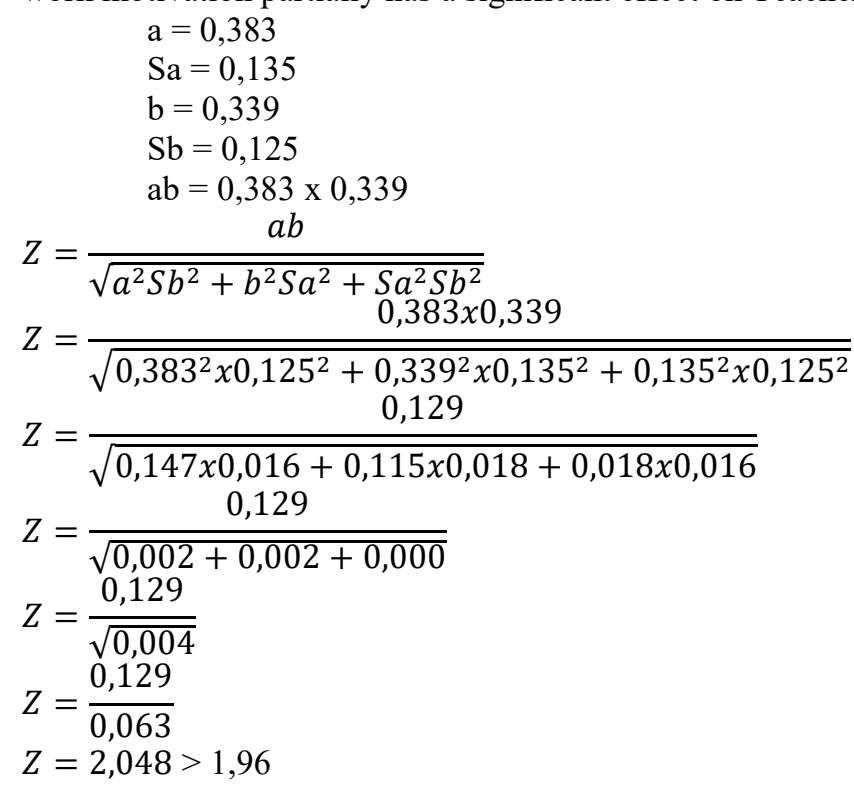

The value $Z=2,048$ where this value greater than 1,96 (with level of significan $5 \%$ ), so it can be said that the Sobel Test results are valid. The total influence of Leadership Style Variables to Teacher Perfomance is $0,147+$ $0,052=0,199 \times 100 \%=1,99 \%$.

c) The amount of influence / contribution each - each variable

Based on tables 4.20 and 4.22 can be obtained the magnitude of each - each influence / contribution of each variable, namely:

a. Contribution of Leadership Style Variables to Teacher Performance

Direct (direct effect) of $0.383 \times 0.383=0.147$

Indirectly (indirect effect) of $0.135 \times 0.383=0.052$ then testing the Sobel Test, namely:

$\mathrm{Z}$ count $=\mathrm{ab}$

Sat

Where is $\mathrm{Sab}=\sqrt{ }(\mathrm{a} 2 \mathrm{Sa} 2+\mathrm{b} 2 \mathrm{Sb} 2+\mathrm{Sa} 2 \mathrm{Sb} 2)$

Known value:

$\mathrm{a}=0.383$

$\mathrm{Sa}=0.135$

$\mathrm{b}=0.339$

$\mathrm{Sb}=0.125$

$\mathrm{ab}=0.383 \times 0.339$

$\mathrm{Z}=\mathrm{ab} / \sqrt{ }\left(\mathrm{a}^{\wedge} 2 \mathrm{Sb}^{\wedge} 2+\mathrm{b}^{\wedge} 2 \mathrm{Sa}^{\wedge} 2+\mathrm{Sa}^{\wedge} 2 \mathrm{Sb}^{\wedge} 2\right)$ 
$Z=0,383 \times 0,339 / \sqrt{ }(\llbracket 0,383 \rrbracket \wedge 2 \llbracket x 0,125 \rrbracket \wedge 2+\llbracket 0,339 \rrbracket \wedge 2 \llbracket x 0,135 \rrbracket \wedge 2+\llbracket 0,135 \rrbracket \wedge 2 \times \square 0,125 \rrbracket$

$\wedge 2)$

$\mathrm{Z}=0.129 / \sqrt{ }(0.147 \times 0.016+0.115 \times 0.018+0.018 \times 0.016)$

$Z=0.129 / \sqrt{ }(0.002+0.002+0,000)$

$Z=0.129 / \sqrt{ } 0.004$

$Z=0.129 / 0.063$

$\mathrm{Z}=2,048>1,96$

obtained the value of $\mathrm{Z}$ count $=2.048$ where the value is greater than 1.96 (in this study using a significant level $5 \%$ ), so it can be said that the Sobel Test results are valid. The total influence of leadership style variables on performance is $0.147+0.052=0.199 \times 100 \%=1.99 \%$.

b.Contribution of Work Discipline Kontribusi to Perfomance Theacer

1) Direct Effect $0,576 \times 0,576=0,331$

2) Indirect Effect $0,158 \times 0,576=0,091$ so doing a Sobel Test

$\mathbf{Z}$ hitung $=\underline{\mathbf{a} \mathbf{b}}$

$\mathbf{S}_{\mathbf{a b}}$

$S_{a b}=\sqrt{b 2 S a 2+a 2 S b 2+S a 2 S b 2}$

$\mathrm{a}=0,576$

$\mathrm{Sa}=0,151$

$\mathrm{b}=0,339$

$\mathrm{Sb}=0,158$

$\mathrm{ab}=0,576 \times 0,339$

$Z=\frac{a b}{\sqrt{a^{2} S b^{2}+b^{2} S a^{2}+S a^{2} S b^{2}}}$

$Z=\frac{0,576 x 0,339}{\sqrt{0,576^{2} x 0,158^{2}+0,339^{2} x 0,151^{2}+0,151^{2} x 0,158^{2}}}$

0,195

$Z=\frac{0,195}{\sqrt{0,332 \times 0,025+0,115 \times 0,023+0,023 \times 0,025}}$

$Z=\frac{0,108}{\sqrt{0,009+0,003+0,001}}$

$Z=\frac{0,195}{\sqrt{0,013}}$

$Z=\frac{0,195}{0,013}$

$Z=1,711<1,96$

The value $Z=1,711$ where this value greater than 1,96 (with level of significan $5 \%$ ), so it can be said that the Sobel Test results are not valid. The total influence of Work Discipline to Teacher Perfomance is $0,331=0,331$ x $100 \%=33,1 \%$.

b. Variable Contributions to Work Discipline on Teacher

Performance Directly the direct effect is $0.576 \mathrm{X} 0.576=0.331$ Indirectly (indirect effect) of $0.158 \mathrm{X} 0.576=$ 0.091 then tested by the Sobel Test, namely: $\mathrm{Z}$ count $=\mathrm{a}$ b Sat Where is $\mathrm{Sab}=\sqrt{ }(\mathrm{b} 2 \mathrm{Sa} 2+\mathrm{a} 2 \mathrm{Sb} 2+\mathrm{Sa} 2 \mathrm{Sb} 2)$

Known value: $\mathrm{a}=0.576$

$$
\begin{aligned}
& \mathrm{Sa}=0.151 \\
& \mathrm{~b}=0.339
\end{aligned}
$$$$
\mathrm{Sb}=0.158
$$$$
\mathrm{ab}=0.576 \times 0.339
$$$$
\mathrm{Z}=\mathrm{ab} / \sqrt{ }\left(\mathrm{a}^{\wedge} 2 \mathrm{Sb}^{\wedge} 2+\mathrm{b}^{\wedge} 2 \mathrm{Sa}^{\wedge} 2+\mathrm{Sa}^{\wedge} 2 \mathrm{Sb}^{\wedge} 2\right) \mathrm{Z}=0.576 \mathrm{x} 0.333 / \sqrt{ }(\llbracket 0.576 \rrbracket \wedge 2 \llbracket \mathrm{x} 0.158 \rrbracket \wedge
$$

$2+\llbracket 0.339 \rrbracket \wedge 2 \llbracket \mathrm{x} 0.151 \rrbracket \wedge 2+\llbracket 0.151 \rrbracket \wedge 2 \mathrm{x} \llbracket 0.158 \rrbracket \wedge 2) Z=0.195 / \sqrt{ }(0.332 \times 0.025+0.115 \times 0.023+$ $0.023 \times 0.025) Z=0.108 / \sqrt{ }(0.009+0.003+0.001) Z=0.195 / \sqrt{ } 0.013 Z=0.195 / 0.013 Z=1.711<1.96$

The value of $Z$ calculated $=1.711$ where the value is smaller than 1.96 (in this study using a significant level of $5 \%$ ), so that the Sobel Test results can be said to be invalid. The total effect of work discipline variables on teacher performance is $0.331=0.331 \times 100 \%=33.1 \%$.

c. Contributions to Work Motivation on Teacher

Performance From table 4.22 it is known as 0.339 X $0.339=0.115 \mathrm{X} 100 \%=11.5 \%$.

d) Coefficient of Determination / R2

The determination coefficient value is determined by the $\mathrm{R}$ square value as can be seen from table 4.21 , it is known that the coefficient of determination / R2 is 0.901 . This means $0.901=90.1$, which is $100 \%-90.1 \%=9.010 \%$, which means that leadership style variables, work discipline and work motivation simultaneously contribute to 
teacher performance by $90.1 \%$, while the remaining $9.010 \%$ is influenced by variables others who did not participate in this study.

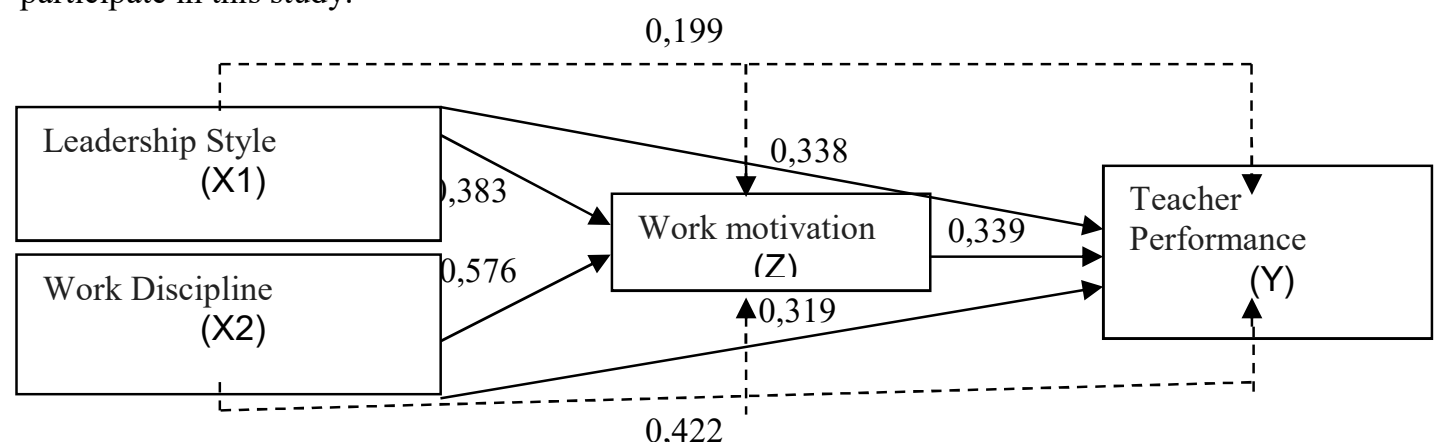

Figure 4.5 Path Diagram Structure 2

Information :

Source: Processed obtained, 2018

$$
\begin{array}{ll} 
& : \text { Direct influence } \\
& : \text { Indirect influence }
\end{array}
$$

Based on the table above it can be seen that

1. Partial or individual leadership style has significant influence or contribution to work motivation of 0.383 , and the total effect is $0.383 \times 100 \%=14.66 \%$. This means that contributions v

2. Variables of leadership style on work motivation are $14.66 \%$ while the remaining $85.34 \%$ are influenced by other variables. The magnitude of the contribution of leadership style variables to work motivation is smaller when compared to the contribution of work discipline variables to work motivation. With the existence of a good leadership style it will bring a positive impact on work motivation.

3. Work discipline partially or individually has a significant effect on work motivation of 0.576 , and the total effect is $0.576 \times 100 \%=57.6 \%$. This means that the contribution of work discipline variables to work motivation is $57.6 \%$ while the remaining $66.83 \%$ is influenced by other variables. The magnitude of the contribution of work discipline variables to work motivation is greater than the contribution of leadership style variables to work motivation.

4. Partial or individual leadership style has a significant effect on teacher performance by 0.147 , and the total effect is $0.147 \times 100 \%=14.7 \%$. This means that the contribution of leadership style variables to teacher performance is $14.7 \%$ while the remaining $85.3 \%$ is influenced by other variables. The magnitude of the contribution of leadership style variables to teacher performance is smaller than the contribution of work discipline variables to teacher performance.

5. Work discipline partially or individually has a significant effect on teacher performance by 0.331 , and the total effect is $0.331 \times 100 \%=33.1 \%$. This means that the contribution of work discipline variables to teacher performance is $33.1 \%$ while the remaining $66.9 \%$ is influenced by other variables. The magnitude of contribution of work discipline variables to teacher performance is greater than the contribution of variable leadership styles to teacher performance.

6. Partial or individual work motivation has a significant effect on teacher performance by 0.339 , and the total effect is $0.339 \times 0.339=0.115 \times 100 \%=11.5 \%$. This means that the contribution of work motivation variables to teacher performance is $11.5 \%$ while the remaining $88.5 \%$ is influenced by other variables.

7. The leadership style has a significant indirect effect on teacher performance through work motivation with a direct effect of 0.147 and the indirect effect of 0.052 and the total effect $(0.147+0.052)=0.199$. Shows that the leadership style coefficient value has an indirect effect smaller than the direct influence leadership style coefficient $(0.052<0.147)$. Then it can be explained that the work motivation variable acts as an intervening variable and the influence of leadership style on teacher performance.

8. Work discipline has an indirect significant effect on teacher performance through work motivation with a direct effect of 0.331 and the indirect effect of 0.091 and the total effect $(0.331+0.091)=0.422$. Shows that the coefficient of work discipline has an indirect effect greater than the coefficient of work discipline direct influence $(0.091<0.331)$. Then it can be explained that motivational variables work as intervening variables and the influence of work discipline on teacher performance.

\section{BIBLIOGRAPHY}

Akbar, Raja Bahrial, 2013, Analysis of the Influence of Leadership, Career Development and Job Satisfaction on Employee Performance, Case Study of the Riau Provincial Liaison Agency in Jakarta, Syarif Hidayatullah UIN thesis, Jakarta.

Danuarta, Adad, 2014, Human Resource Management Work Motivation and Leadership Style, http://adaddanuarta.blogspot.com, November 7, 2014. 
Fahmi, Irham, 2016, Introduction to Human Resource Management Concepts and Performance, Jakarta, Mitra Wacana Media.

Fitriani, Eka, 2016, Effect of education level, work motivation, work experience and job satisfaction on employee work productivity at the DJM machine repair shop, Sidoarjo.

Ida, N.H., Margono, S, Solimun, 2013, Emotional Intelligence and Spiritual Intelligence Influence on Job Satisfaction and Employee Performance, Journal of Management Application, Vol. 11, No.4, December 2013, pp. 629-639.

Laksono, Drajat, 2016. Effects of Compensation and Motivation on Employee Job Satisfaction and Its Impact on Employee Performance at Rangkah Puskesmas Surabaya. Stie Mahardhika Surabaya Thesis.

M.Sc., Sutrisno Edy, Prof. Dr. H, 2016, Human Resource Management, Jakarta, Private Vocational School, Group.

Mulyadi, S.E., M.M., 2016, Human Resources Management (Hrm), Bogor, In Media.

Mangkunegara, Anwar Prabu, 2014. Human Resource Management. Bandung, PT. Ramaja Rosdakarya.

Nurdiyanta, 2016, Analysis Of The Impact Of Leadership Style, Work Motivation, Communication Style And Discipline Of Work On Teacher Performance In Karanganyar, Things: 8-26 and 31-32.

Nurdiyanta, 2016, Impact analysis of Leadership Style, Work Motivation, Communication Style and Work Discipline on Teacher Performance in Karanganyar, Thesis, Surakarta Muhammadiyah University.

Prasetiyo, Sigit, 2014, Effect of Leadership and Compensation Style on Employee Performance with Job Satisfaction As Intervening Variables, Thesis, Yogyakarta State University.

Sinambela, Poltak, Prof. Dr. Lijan, 2016, Human Resource Management, Jakarta, Askara Earth.

Sugiyono, Dr., Prof., 2013, Quantitative, Qualitative And R \& D Research Methods, Alfabeta, Bandung.

Setiawan, Fendry, Pengertian Type of Theory and Leadership Style, http://fendrysetiawan21.bloqspot.co.id, 11 December 2014.

Siregar, Sofiyan, 2013. Quantitative Research Methods; Equipped with Comparison of Manual Calculation \& SPSS. Kecana, Jakarta. 